Click www.researchjournal.co.in/online/subdetail.html to purchase.

Volume 5 | Issue 2 | September, 2014 | 197-200 — e ISSN-2231-6434 |

International Research Journal of Agricultural Economics and Statistics

Visit Us - www.researchjournal.co.in DOI : 10.15740/HAS/RJAAES/5.2/197-200

\title{
Research Paper Marketing of minor millets grown in tribal Dang district of South Gujarat
}

口 J.J. MAKADIA, K.S. PATEL AND N.J. AHIR

See end of the paper for authors' affiliations

Correspondence to :

\section{J.J. MAKADIA}

Department of

Agricultural Economics

N.M.College of Agriculture

Navsari Agricultural

University

NAVSARI (GUJARAT) INDIA

Email:jjmakadia@yahoo.

com

Paper History :

Received : 12.05 .2014

Revised : 03.07.2014;

Accepted: 19.07 .2014
ABSTRACT : Minor millets are one among the traditional group of cereal crops and are cultivated in areas where they produce a more dependable harvest compared to any other crops. The present study is an effort in this direction to study all the aspects of marketing of minor millets namely, kodra(Paspalum scrobiculatum), finger millet(Eleusine coracana), and vari (Panicum miliare) grown in tribal and hilly Dang district of South Gujarat region. The primary data were collected with the help of well designed questionnaires consisting of 120 sample farmers, 40 farmers for each crop. To derive the results, simple average and tabular analysis were used. The total marketable surplus of kodra, finger millet and vari was 12.33, 27.01 and 159.23 qtls., respectively. The per quintal marketing cost of farmers for kodra, finger millet and vari was Rs.16.08, Rs.18.50 and Rs.20.10, respectively. The proportion of price spread was found highest in kodra (31.15\%) and the lowest in vari. (16.67 \%). The market margin was Rs.314.15, Rs.277.40 and Rs.152.15 per quintal in vari, finger millet and kodra, respectively.

KEY WORDS : Marketable surplus, Price spread, Marketing cost, Minor millets, Tribal area

HOW TO CITE THIS PAPER : Makadia, J.J., Patel, K.S. and Ahir, N.J. (2014). Marketing of minor millets grown in tribal Dang district of South Gujarat. Internat. Res. J. Agric. Eco. \& Stat., 5 (2) : 197-200. 